\title{
When the workplace is the home: labour inspectors' discretionary power in the field of domestic work - an institutional analysis
}

\author{
Rebecca Paraciani and Roberto Rizza* (D) \\ University of Bologna, Italy \\ *Corresponding author. Email: roberto.rizza@unibo.it
}

(Received 22 November 2018; revised 27 August 2019; accepted 16 September 2019)

\begin{abstract}
This article builds on previous studies concerning the question of street-level bureaucracy, an expression coined by Lipsky (1980) - Street-Level Bureaucracy. Dilemmas of the Individual in Public Services (New York: Russel Sage Foundation) - to highlight the importance of the discretionary power that professionals in public agencies exercise during the implementation of laws, standards and guidelines. Discretion may depend on the need to compromise between the limited resources available and the claims of citizens, or between administrative policy directives and assessments, on the one hand, and their interpretation by "street-level" bureaucrats, on the other. This article focuses on the dilemmas that labour inspectors face when dealing with employment irregularities involving domestic workers. Based on nine months of observations in a local office of the Italian Labour Inspectorate, it aims to understand how labour inspectors make use of their discretionary power when the workplace is the home. This article connects studies of street-level bureaucracy with the new institutional organisational analysis, focusing on the isomorphic pressures from the institutional field in which the labour inspectors operate, together with the manner in which such pressures shape labour inspectors' discretion. Through this connection, the article aims to extend the scope of both theories.
\end{abstract}

Keywords: domestic workers; ethnography; institutional field; isomorphism; labour inspectors; street-level bureaucracy

\section{Introduction}

Lunch break.

Inspector 2 tells me that discretion in their work does not exist. "If a colleague tells you that they are free to behave as they want, then they are acting illegally, breaking a law, a directive, a regulation. We are not free." Inspector 12 tells him that he is being cynical. "We are people first and foremost, and then labour inspectors. We are not robots. We 
must reflect on the situation before acting, in order to do the right thing." Inspector 2 tells her that she is an idealist, as always.

Inspector 2, M Inspector $15, \mathrm{~F}$ Field Note, 05/2017

This article refers to the series of studies of what has been termed street-level bureaucracy, an expression coined by Lipsky (1980) to highlight the importance of the discretionary power that professionals in public agencies exercise when implementing standards and guidelines. Discretion may depend on the need to find compromises between the limited resources available and the claims of citizens, or between administrative policy directives and the assessment of performance standards required of street-level bureaucrats (Hupe 2013).

Labour inspectors, in this sense, are street-level bureaucrats. These civil servants monitor, verify and judge any breaches in the workplace relating to the losses suffered by workers. In pursuing this goal, they adapt the rules to specific cases, and interpret laws according to the circumstances in which they operate. In this sense, they exercise a substantial degree of discretion by adopting margins of autonomy when applying directives dealing with various dilemmas (Raaphorst and Loyens 2018).

Inspectors' discretionary power affects policy delivery and the rules or procedures to be applied (Riccucci 2005). While acting, they deal with different types of dilemmas regarding their interpretation of the applicable procedures, and ultimately establish what is to be considered an emergency. Through their practices, they "help to create and to maintain a normative order" (Maynard-Moody and Musheno 2003, 23).

Dilemmas refer to all those situations in which values are in conflict (Cooper 2001), such as when fairness as perceived by street-level bureaucrats contrasts with the correctness of the procedure (Kelly 1994; Maynard-Moody and Musheno 2003; Epp 2009), or when legality and efficiency clash ${ }^{1}$ (Loyens 2016).

A typical dilemma for labour inspectors occurs when the home is the workplace, as in the case of those jobs performed by domestic workers, a category of workers considered vulnerable due to several factors, as will be specified. In this domain, labour inspectors have to decide how to manage work irregularities within that private space, defined as "inviolable" by Article 14 of the Italian Constitution.

The power of access to workplaces is the most distinctive one attributed to inspectors, as it grants them access at any time to any place of work. However, what happens when the workplace is a private domicile, and as such a constitutionally inviolable sphere of private life?

This article, based on a nine-month ethnographic analysis carried out at a local office of the Italian Labour Inspectorate, aims to establish the manner in which labour inspectors make use of their discretionary power when dealing with domestic work irregularities. More specifically, it shall address the following questions: (1) what happens to labour inspectors' power of access when the workplace is a private home; (2) how do labour inspectors manage their discretionary power in

\footnotetext{
${ }^{1}$ Street-level bureaucrats often have to deal with situations in which formal rules conflict with other values, or in which formal procedures are considered a waste of time and inefficient.
} 
order to resolve this dilemma; (3) what institutional factors contribute towards shaping their way of processing domestic workers' complaints?

The authors intend to discuss these issues by considering street-level bureaucrats not only as rational actors with individual preferences, but also as actors embedded in a broader institutional field (DiMaggio and Powell 1983) that shapes their use of discretionary power (Garrow and Grusky 2012; Rice 2012; Epp et al. 2017).

This article intends to introduce neo-institutional organisational analysis to research into street-level bureaucracy, in this way extending the scope of both theories. From this perspective, on the one hand, it will be clear how institutional pressures within an organisational field impact inspectors' actions by reducing their discretionary space; on the other hand, it will provide an insight into how aspects linked to the professionalisation process, and the different ideas inspectors have developed regarding domestic work irregularities, each entail a different operative logic.

\section{Labour inspectors as street-level bureaucrats}

Labour inspectors can be considered to be street-level bureaucrats (Fineman 1998). Using Lipsky's words, those who work within control and vigilance agencies, as street-level bureaucrats, "decide who to sanction, determining the nature and quality of the sanction" (Lipsky 1980, 13). In fact, labour inspectors have to implement personal solutions when dealing with work irregularities, whereby they are called on to decide whether, and in what way, to gain access to the workplace for inspection purposes, and to find a solution that is to the worker's benefit. Legislative, organisational and regulatory guidelines are not always formulated in a clear, unambiguous way, and they are implemented through a process of adaptation, redefinition and reinterpretation of the law on behalf of the actors (Saruis 2015).

Piore and Schrank $(2006,2008)$ try to assess the role of inspectors in ensuring decent working conditions within two different institutional contexts - Latin America and the United States - and investigate the relationship between business practices and "decent work" standards. According to them, the "Latin model" is more adaptable than the US one, because it gives inspectors greater discretionary power. Latin labour inspectors are defined as an "assault troop" (Piore and Schrank 2008, 20), and their job and goals are defined by practices embedded in the culture of the inspectorate body and passed on from one generation to the next.

Other studies (Nielsen 2007; Loyens 2016) investigate the way in which personal and contextual aspects may influence labour inspectors' decisions regarding how cases of forced labour can be resolved. These ethnographic studies show how the perception of severity of certain situations determines priorities when searching for solutions. This conclusion is reached by identifying different coping strategies. The solution of a case is not solely motivated by the desire to obtain the right treatment for the victim of labour abuse, but also by the need to achieve personal "outgrowth" inasmuch as the number of arrests and resolved cases constitutes an indicator of the quality of an inspector's performance.

Although scholars generally agree that inspectors have considerable discretionary power, there is no one definition of discretion (Hawkins 1984; Gilboy 1992; Kluin 2014). On a general level, discretion includes all aspects of an inspection process: 
when to visit, how carefully evidence is to be collected, how to interact with witnesses and employers (Goosensen and Van der Voort 2009; Goosensen and Van Bueren 2011; Kluin 2014). However, there is a further discretionary power concerning the penalty to be applied (Wiering 1999; May and Wood 2003; Lehmann Nielsen 2006). Davis $(1969,4)$ tries to provide a standard definition, arguing that "a public officer has discretion wherever the effective limits of his power leave him free to make a choice between possible courses of action and inaction".

A substantial body of research distinguishes two main interpretative strands. The first one sees discretion as the degree of freedom that the legislator grants to these workers. Alternatively, the same term is used to define the way in which the granted freedom is effectively used (Hupe et al. 2015).

Discretion leaves spaces open for the making of decisions. Street-level bureaucrats use discretion mainly to give meaning to certain policy standards and to establish a balance between the requests addressed to them and the resources actually available (Lipsky 1980; Evans and Harris 2004; Hupe and Hill 2007; Brodkin and Marston 2013; Hupe and Buffat 2014).

Discretion can be defined as: (i) discretion within the framework of laws and procedures; (ii) discretion among the laws and procedures to be applied; (iii) discretion beyond the boundaries of laws and procedures.

Discretion is operated within the law because street-level bureaucrats adapt norms to concrete situations. When the law is unclear and/or contradictory, street-level bureaucrats interpret it by acting among the law. In the third case, when discretion means acting beyond the confines of the law, it consists in a violation of formal rules (Ham and Hill 1986; Kazepov and Barberis 2012).

This article focuses on the way in which inspectors implement their discretionary power within a particular institutional field - that of paid domestic work - where the private home constitutes the workplace. An organisational field is defined as "the set of organisations which, taken together, constitute a recognised area of institutional life" (DiMaggio and Powell 1983, 91). According to this definition, organisational fields are constituted by actors who interact frequently and who establish socially acceptable standards of actions. Organisational fields include companies, state authorities, associations, unions, professional bodies, knowledge centres, mass media and all those actors who, through their interaction, produce institutional logics. Such logics derive from routinised actions that are institutionalised. They regulate actors' activity by establishing criteria of legitimacy (Geertz 1982; DiMaggio and Powell 1983), and ultimately establish the right way to act. The similarity between the parts of the field is given by the effect of isomorphic pressures leading to the adoption of standardised practices and procedures (DiMaggio and Powell 1983). Powell and DiMaggio identify three types of isomorphism: coercive, mimetic and normative, which will be examined in the following paragraph.

\section{Paid domestic work in Italy}

The feminisation of migratory flows (Castles and Miller 1993; Bettio et al. 2006) has made it increasingly common in Europe to employ migrant women in domestic, care and cleaning activities (Anderson 2007). The carers, or badanti, are domestic 
Table 1. Domestic workers in Italy by year and gender

\begin{tabular}{|c|c|c|c|c|c|}
\hline \multirow[b]{2}{*}{ Year } & \multicolumn{4}{|c|}{ Gender } & \multirow[b]{2}{*}{ Total \% } \\
\hline & Male & $\%$ & Female & $\%$ & \\
\hline 2012 & 191,300 & 18.9 & 821,688 & 81.1 & 100 \\
\hline 2013 & 159.401 & 16.6 & 801,612 & 83.4 & 100 \\
\hline 2014 & 121,210 & 13.3 & 790,289 & 86.7 & 100 \\
\hline 2015 & 110,909 & 12.4 & 785,293 & 87.6 & 100 \\
\hline 2016 & 104,644 & 12.0 & 768,606 & 88.0 & 100 \\
\hline 2017 & 101,269 & 11.7 & 763,257 & 88.3 & 100 \\
\hline
\end{tabular}

Source: INPS, observatory on domestic workers: figures processed by the authors.

workers assisting elderly and disabled people. With the term "cleaner" we refer to those domestic workers involved in cleaning other people's homes (Andall 2000).

These working activities are also considered at risk of irregularities and exploitation (FRA 2015), and are part of what Piore (2011) defines as the secondary labour market, consisting of precarious, poorly paid and socially penalising jobs (Ambrosini 2005).

The lack of knowledge of the local language, the need to have a job in order to obtain and maintain a valid residence permit, and in some cases the non-recognition of their qualifications make immigrants vulnerable workers. In Italy, according to INPS data, ${ }^{2}$ the composition by gender of this category shows a growing prevalence of female domestic workers (Table 1). ${ }^{3}$

In 2017, women employed in the domestic sector constituted $88.3 \%$ of the total workforce (763,257 in absolute figures) and were of predominantly Eastern European origin ( $43.7 \%$ of the total).

Domestic workers are considered to constitute a vulnerable category, not only for being mostly foreign and female, but also as a consequence of the places where they work. A recent research conducted by the European Union Agency for Fundamental Rights (FRA 2015) showed how their isolation makes these workers more exposed to the risk of being exploited and being subjected to irregular working conditions. Within the domestic sphere, employment contracts are often absent or not complied with. In Italy, Law 339 was adopted in 1958 to establish a system of domestic labour regulation, and it is considered the first step towards the specific recognition of care work, which perpetually straddles the formal and informal divide, and up until 2007 was without any national collective agreement, unlike other areas of employment in Italy (Sarti 2010). The aforesaid Law established: eight occupational levels, based on a worker's qualifications; working hours standards ${ }^{4}$; resting requirements and the possibility of changing shifts.

Although the goal of these measures was to extend domestic workers' social protection, there is still a gap between domestic work and other areas of employment.

\footnotetext{
${ }^{2}$ Data have been collected by the observatory INPS on domestic workers: https://www.inps.it/ webidentity/banchedatistatistiche/menu/domestici/main.html

${ }^{3}$ The statistical unit is represented by the domestic worker who has received at least one contributory payment during the last year.

${ }^{4}$ Working hours were set at 40 hours a week for workers who do not live in the place where they work, and at 54 hours a week for live-in workers.
} 
Table 2. Observed interaction between labour inspectors and domestic workers, and the discretionary spaces concerned

\begin{tabular}{|c|c|c|c|c|}
\hline \multirow[b]{2}{*}{ Types of worker } & \multicolumn{2}{|c|}{ Discretionary spaces } & \multirow[b]{2}{*}{ Investigative phase } & \multirow[b]{2}{*}{ Tota } \\
\hline & Complaints desk & $\begin{array}{l}\text { Dispute settlement } \\
\text { facility room }\end{array}$ & & \\
\hline Carer & 9 & 22 & 1 & 32 \\
\hline Cleaner & 3 & 6 & 0 & 9 \\
\hline Total & 12 & 28 & 1 & 41 \\
\hline
\end{tabular}

Source: Authors' field notes.

Furthermore, the high degree of informality that characterises both the workplace and working relationships leads many employers (families) not to apply the recently introduced national collective agreement. This means that a large part of domestic work is not declared for tax and social insurance purposes (Sarti 2010).

\section{Data collection and fieldwork: the institutional context}

Data were collected through the adoption of an ethnographic method permitting continued observation and consisting in the drafting of field notes (Fassin 2013). During the observation period, the analysis focused on labour inspectors' ways of dealing with domestic work irregularities. Observations were recorded inside a local office of the Italian Labour Inspectorate, for a period of nine months starting from February 2017..$^{5}$

The data collected by means of participant observation were transcribed from the field notes taken.

During the participant observation period, 41 cases of interaction between labour inspectors and domestic workers were observed. Thirty-two of these cases involved labour inspectors and carers, while nine involved labour inspectors and cleaners. All domestic workers complain of employment irregularities.

Twenty-eight cases of interaction were observed during dispute settlement procedures before the inspection. This consists of a specific procedure provided for by Italian law to settle wage-related and insurance contribution-related employment disputes. Twelve cases were observed at a complaints desk, where workers submit complaints regarding their irregular employment situation (Table 2).

Observing labour inspectors' decisionmaking from their perspective offers the opportunity to focus on ordinary events in natural settings and to learn about the inspectors' strategies and motivations. Ethnography, furthermore, permits an analysis of discourse 6 both during formal interaction and conducted in informal settings, thus bringing out the relational dynamics concerned.

\footnotetext{
${ }^{5}$ Observations were conducted within the framework of a broader ongoing research project. For the purposes of this article, only cases of interaction between labour inspectors and domestic workers have been analysed.

${ }^{6}$ Discourse analysis is defined as the analysis of language beyond the sentence. The main goal is to study the content of speech in order to understand how it affects the meaning of the sentence.
} 
Labour inspectors were observed in three "discretionary spaces": (1) the complaints desk, (2) settlement proceedings before a single judge, (3) office work during the investigative phase. The complaints desk comes into play when a worker complains about his/her irregular employment situation. In such cases, the labour inspector may decide to proceed with an investigation, or look for an administrative solution (by means of the dispute settlement facility), or not open the case at all. The dispute settlement facility represents a specific procedure provided for by Italian law no. $124 / 2004$ and is designed for the purpose of settling wage-related and insurance contribution-related employment disputes. If no agreement is reached between the worker and employer, then an inspection has to be carried out. In such cases, the labour inspector is an impartial third party who, on the basis of workers' statements submitted to him/her, aims to find an administrative solution that suits both parties. If the dispute is settled at this stage, the employer will not be subject to any penalty. Labour inspectors use their discretionary powers to encourage the parties to come to a financial agreement, or to discourage domestic workers from accepting the conciliatory procedure. During the investigative phase, the labour inspectors may decide how to collect information on the case, and whether to proceed with a workplace inspection or not.

What happens, however, when the workplace is the home? Are labour inspectors to interpret the home as an "inviolable" private sphere in accordance with Article 14 of the Italian Constitution?

Which institutional factors shape labour inspectors' decisionmaking?

Dilemmas arise mainly as a result of the fact that labour inspectors cannot always launch an investigation in every single case: time, resources and staff are not sufficient to be able to deal with all complaints received. Furthermore, not all cases can be dealt with through a reconciliation procedure: first of all, because the success of the dispute settlement facility depends on the existence of an agreement between parties involved, and in the absence of such an agreement a mandatory investigation should be launched; secondly, not all disputes can be resolved through a financial transaction. Indeed, according to Article 2112 of the Italian Civil Code, a violation of human rights such as the refusal to grant workers a certain number of hours of rest each day, or the failure to pay a minimum wage, cannot be settled by the offer of financial compensation. However, the dispute settlement facility is often the preferred method of resolving these violations.

Finally, the labour inspectors' operations have to comply with the standards established by the central authority.

Based on a multi-level approach, this analysis examines street-level bureaucrats' discretionary actions as influenced by the institutional logic of the organisational field in which they operate (Garrow and Grusky 2012; Rice 2012; Thornton and Ocasio 2017). As mentioned before, an organisational field includes all those actors (institutional and non-institutional) whose role it is to establish socially acceptable standards of action (DiMaggio and Powell 1983). To deal with the dilemma at the centre of this article, labour inspectors make their decisions within the organisational field of domestic workplace controls. There are many different actors operating within this

\footnotetext{
${ }^{7}$ In Italian, this procedure is called "conciliazione monocratica". During this procedure the labour inspector is an impartial third party tasked with finding an administrative solution to the dispute between the worker and employer. This procedure precedes inspections, and enables several cases to be resolved in a short time.
} 
organisational field. The state, through the Ministry of Labour and Social Policies, establishes national guidelines in the field of labour protection which define priorities in terms of actions and controls. Institutional actors operating within the field also include control agencies and inspection bodies, such as the National Labour Inspectorate, the National Social Insurance Institute (INPS), the National Institute for Insurance against Accidents at Work (INAIL), and the Carabinieri's Employment Unit. The field also comprises labour inspectors, domestic workers, employers, trade unions, journalists and the public.

The organisational field of domestic workplace control is characterised by a move towards the establishment of standardised operational procedures and systems of accountability that are the result of organisational change aimed at replacing "the alleged inefficiency of hierarchical bureaucracy with the alleged efficiency of the markets" (Power 1997, 61). The concept that best captures the process of homogenisation is isomorphism (DiMaggio and Powell 1983). Thus, the "managerialisation" of domestic workplace control establishes isomorphic pressures that lead to the adoption of standardised practices and procedures based on evaluation, control and performance criteria (Borghi and Rizza 2006).

These isomorphic pressures generate a change that leads the members of an organisational field to adhere to the established institutional logic. Powell and DiMaggio identify three types of isomorphism: coercive, mimetic and normative. In the first case, the members of an organisational field are subjected to external pressures (e.g. legal constraints) that force them to conform, and these stem from the problem of legitimacy. When isomorphism is mimetic, situations of uncertainty are dealt with by imitating the identified solutions. Isomorphism is normative when professions define their respective working conditions and methods and establish the cognitive base and legitimation for their occupational autonomy: in this case, changing practices are not generated by uncertainty, but by an awareness of their alleged superiority (Bonazzi 2002).

Nevertheless, street-level bureaucrats continue to use their discretionary power of agency and to filter the influence exerted by the organisational field (Garrow and Grusky 2012). The present analysis tries to unveil the interplay between institutional pressures, on the one hand, and the discretionary power of street-level bureaucrats, on the other.

\section{Principal findings: isomorphic pressures and domestic work irregularities}

In 29 of the 41 observed cases of interaction, the home was interpreted as a private place and, for this reason, was deemed inviolable. Furthermore, labour inspectors who see the home as a workplace have not always decided to process the case through an inspection.

The aforementioned dispute settlement procedure is provided for by Italian Legislative Decree no. 124/2004, and is designed to provide an administrative solution to cases of employment irregularity, mainly consisting of wage- and social insurancerelated employment issues reported by workers. This facility precedes an inspection by the Labour Inspectorate, which will only be launched if no agreement is reached between the workers and employers. The labour inspector plays an impartial role, 
acting on the basis of employees' statements in an attempt to find an administrative solution that suits both parties as far as possible. By resolving the dispute at this stage, an employer will avoid any consequent penalty.

In the field of domestic work irregularities, this solution is considered by most labour inspectors as "the only glimmer of hope for these women" (field note) whereby they may obtain some form of financial reimbursement at least. The decision to refer domestic work irregularities to the dispute settlement facility is the result of institutional pressure, from national and local offices, to comply with procedures in keeping with the new organisational logic imposed by the new public management approach to public administration (Ferrari 2002). This may be interpreted as coercive isomorphic pressure exercised by central government, forcing inspectors to conform to defined standards (Borghi and Van Berkel 2007) based on accountability criteria and measurable performance standards.

The spread of this procedure is also demonstrated by the data: at the local office analysed here, cases of irregularities within the domestic sector for which the investigative procedure was launched numbered 47 in 2015, but only 1 in 2016, the year in which the conciliation procedure was introduced. ${ }^{8}$ Since then, conciliation has been obligatory in the case of domestic workers reporting employment irregularities to the complaints desk, regardless of the type of irregularity, thus reducing the risk of legal disputes arising regarding the interpretation of home as inviolable and private, or as a workplace.

Although Article 2113 of the Italian Civil Code states that the violation of workers' rights ${ }^{9}$ should not be remedied by a mere economic transaction (as would be the case with the conciliation procedure), this solution has become a standardised, substantially legitimised procedure.

I ask him if he thinks that the dispute settlement procedure is a fair solution.

"I think that this allows us to speed up proceedings and close many cases."

"We cannot help everyone. When dealing with domestic work, the risk is that of launching an investigation leading to a dead end. These are difficult cases. How do you get access to people's homes? Not everyone lets you in".

In addition to coercive isomorphic pressure, the institutional field is also increasingly characterised by what has been called normative isomorphism. However, in this case inspectors use their discretionary power differently. Normative isomorphic pressures stem from the harmonisation of competencies and an ever-increasing degree of professionalisation. With this in mind, membership strategies have been

\footnotetext{
${ }^{8}$ Data from each local office of the National Labour Inspectorate can be found at: https://www.ispettorato. gov.it/it-it/studiestatistiche.

${ }^{9}$ These include the right to freedom, daily rest, holidays and minimum wages.
} 
developed that delineate the exclusion boundary and delimitate the field of action. However, having taken different paths towards professionalisation, labour inspectors tend to adopt different approaches. Indeed, the ethnographical study highlights two different approaches to inspections when the home constitutes the workplace. More experienced inspectors tend to see the protection of workers' rights as their main duty. Despite organisational field pressures encouraging recourse to the dispute settlement facility, inspectors with greater professional experience disagree with this method.

The worker, from Ukraine, is a live-in caregiver, despite her part-time contract. She shows us photos of a bare room where she has been sleeping for a year and a half. ( . . . ) When I was alone with Inspector 3, he told me that he doesn't want to bring this case before the labour inspection for conciliation, but wants to carry out an inspection. "I've been doing this job for 20 years. Things change, I know it. I should push for conciliation so we can speed things up, but I disagree. I would go to the house of that person (referring to the employer) without even asking permission. Her house is a place of work."

Inspector 3, $\mathrm{M}$

Field Note, 09/2017

Experienced inspectors often refer to the number of cases they have dealt with during their long careers.

"I have been doing this job for 19 years. 19 years is a lot. And frankly, I don't like the fact that someone who has only studied things in books tries to tell me how I should do my job".

Inspector $10, \mathrm{M}$

Field Note, 07/2017

Inspector 17 is drinking her coffee and is disappointed. She tells me that sometimes she is not sure about the sense of her job. "Can you imagine it? From 1996 to 2004, we did eight inspections every day. Everything was simple. Procedures were simple. Now there is a lot of bureaucracy and many organizational problems. I cannot waste my time. Is the home a private place? Is it a workplace? It's a waste of time. Is she (referring to a domestic worker) working there? Okay, in this case we have to make an inspection".

Inspector $17, \mathrm{~F}$

Field Note, 09/2017

The younger inspectors, unlike the older ones, must hold a university degree. They are trained to consider the efficiency of their operations as their main goal. A labour inspector is considered efficient if he/she can solve as many cases as possible. Accountability criteria and the measurement of performance are the primary objectives for the purposes of the achievement of quantified standards. This is reflected in their way of working, which leads them to prefer the dispute settlement procedure.

When they (domestic workers) come to complain about their situation ... well ... it is always easy, because you don't have to think about it too much (...) you do not have 
much of a choice. The home is not a normal place of work, and so if you want to help them you should refer their cases for dispute settlement by means of conciliation. But if conciliation doesn't work, then that's a problem.

Inspector 12, talking about the accountability practices adopted in the local office and about the new practices introduced to speed up procedures, tells me that he is very happy and mentions the difference between "junior" and "senior" inspectors. "They (senior inspectors) feel restricted by all these performance standards. I believe, on the contrary, that they are necessary in order to communicate what we do, not only to those above us (interregional and central offices), but also to the outside. Numbers are necessary."

Mimetic pressures operate to reduce uncertainty about the outcome of inspections, by encouraging the adoption of standardised strategies (Flood and Fennell 1995). As a result, there is a trend towards managing employment irregularities in the domestic sector through recourse to the conciliation procedure. Faced with the uncertain outcome of inspections, domestic workers who appeal to the complaints desk are encouraged by inspectors to follow the route of conciliation. This procedure represents the fastest way of solving such cases, although for the worker it means giving up those rights that could not be compensated by money. This trend is also affected by the strong degree of racialisation of the domestic sector, as has been pointed out by a substantial body of research carried out in Italy. The existence of stereotypes of domestic workers can influence the way in which some inspectors manage employment irregularities (Catanzaro and Colombo 2009; Fullin and Vercelloni 2009). This is an external pressure that has been absorbed by the organisation, becoming a routine justifying labour inspectors' working practices. For example, the belief that Romanian workers are "cunning" and "calculating" limits the quality of interaction between labour inspectors and such workers, and reduces the time spent on such cases and the inspectors' willingness to explain to Romanian domestic workers all the possible options available to them. These beliefs compromise the commitment of inspectors, who consequently choose the quickest, least demanding solution, thus reducing the likelihood of lengthy procedures and the uncertain outcome of any inspections.

Inspector 2 interacts using technical language. The worker, a Romanian, is screaming: "I do not understand, you speak in a difficult way. I would like to say why I am here. Because this woman (she means the employer) treats me as a servant! She hasn't paid me for months!"

Inspector 2 looks at her for the first time: "I speak in this way because the law speaks in this way. If you don't understand, you cannot get anything (he means money)." 
It is the third reconciliation procedure in two days involving a domestic worker from Romania. She is a carer. Inspector 13 proceeds as always: he gets the parties to sit down and then gives them the standard information, lets them talk to each other for a while, and then (after no more than ten minutes) draws up the report, copying and pasting the same case from two hours before. When he finishes, he looks at me: "At least in this way (he means via the conciliation procedure) they work things out themselves."

Inspector $13, \mathrm{M}$

Field Note, 04/2017

During the dispute settlement procedure, the domestic worker accused the employer of having been treated for two and a half years as a slave. And she shows the labour inspector a photo of a mattress lying on the floor, where she was forced to sleep. The inspector does not look at the photo, because this is not the right place to show evidence. He then suggests to the domestic worker that it is better to accept the financial agreement, to have some money as soon as possible.

Inspector $6, \mathrm{~F}$

Field Note, 04/2017

"Who tells us that they (he means the domestic workers) did not understand that during the dispute settlement procedure they could get some money and come here to complain exaggerating their situation?"

Inspector $7, \mathrm{M}$

Field Note, 05/2017

"What do they mean by 'working time'? If you're at home smoking cigarettes, you're not working." They laugh over their coffee.

Inspector 6, F; Inspector 15, M

Field Note, 04/2017

A different approach that counters the aforementioned mimetic pressures is adopted by those inspectors who are, or who have been, employers of domestic workers themselves.

I'm a bit sorry for that lady. She reminds me of my Mum's carer, who has become part of my family. I should have insisted so she could have got more.

Inspector $4, \mathrm{~F}$

Field Note, 04/2017

Drinking a coffee, he asks me if my grandparents have a caregiver. I answer no. And he tells me that it is difficult for me to understand how serious it is to treat those caring for your elderly relatives badly.

Inspector $12, \mathrm{M}$

Field Note, 06/2017

The field notes above show how direct experience of domestic workers leads inspectors to perceive these irregularities as more serious, and to being more empathic towards this type of worker. 


\section{Final considerations}

This article explores how labour inspectors use their discretionary power when dealing with employment irregularities in cases where a private home constitutes the workplace. Field notes collected over nine months of participant observation have been analysed. Our findings highlight the fact that the discretionary powers that labour inspectors exercise as frontline workers (Lipsky1980; Caswell et al. 2017) is affected by the institutional pressures embedded in the organisational field of workplace control. We have identified three forms of isomorphic pressure that induce inspectors into adopting solutions whereby reported employment irregularities are referred to the conciliation facility provided by the Labour Inspectorate. These three forms of pressure are: coercive, normative and mimetic. We have also highlighted how such pressures do not eliminate the discretionary spaces within which actors may make their decisions. We illustrate the different courses of action adopted by inspectors in addressing cases of employment irregularity. When normative isomorphism prevails, for example, most inspectors tend to refer these cases to the Labour Inspectorate's conciliation facility, in order to resolve disputes as quickly as possible. However, other inspectors - albeit a small minority - adopt a different attitude, and by appealing to the criteria of justice and the restoration of workers' rights, they believe that employment irregularities in the domestic sphere must be further investigated. Accordingly, normative isomorphism and the reactions of labour inspectors are the result of the interplay of different professionalisation paths. In the case of mimetic isomorphism, the conciliation option is pursued by labour inspectors - a majority - who have interiorised stereotypes of domestic workers influenced by the strong racialisation of this particular sector of the labour market. This trend results in institutional pressure for the adoption of the fastest solution, since the outcome of any inspection is invariably uncertain. The devaluation of domestic work, most of which is done by immigrant women, inhibits further investigation. Nevertheless, other inspectors who themselves employ, or have employed, domestic workers react differently to such institutional pressure, and perceive these irregularities as more serious; consequently, they believe that the conciliation procedure is not enough. By further examining these issues, this article reveals the contribution of the new institutional perspective to the street-level bureaucracy approach. First of all, it enables the complexity underlying caseworker-client interaction to be considered, thus responding to certain critics who see the street-level bureaucracy approach as "context-free" (Berman 1978, 32). Furthermore, the combination of these two frameworks significantly contributes towards our understanding of the implementation of directives and regulations within different institutional fields.

Our research findings generate a number of other questions, and thus further research is required in order to examine frontline workers' discretion within other areas of the labour market than the one analysed here. Moreover, in an attempt to develop the comparative analysis of street-level bureaucracy (Hupe et al. 2015), labour inspectors' discretionary powers in different countries and institutional settings could be examined in depth. Unanswered questions emerge from our research: is the standardisation of the organisational practices followed in dealing with employment irregularities a way of protecting highly discriminated workers, or does 
it result in a deterioration in the quality of those actions taken? How, and to what degree, does single-judge reconciliation mean a loss of rights, also when comparing domestic to non-domestic work? What are the consequences of this type of decision? Furthermore, can the number of cases that have been solved through the single-judge reconciliation procedure, compared to the number of cases solved subsequent to inspections, be quantified?

Acknowledgements. None.

Data Availability Statement. This study does not employ statistical methods, and no replication materials are available.

\section{References}

Ambrosini M (2005) Sociologia delle migrazioni. Bologna: Il Mulino.

Andall J (2000) Gender, Migration and Domestic Service. The Politics of Black Women in Italy. London: Routledge.

Anderson B (2007) A Very Private Business. Exploring the Demand for Migrant Domestic Workers. European Journal of Women's Studies, 14(3): 247-264.

Berman P (1978) The Study of Macro and Micro Implementation of Social Policy. Santa Monica, CA: RAND Corporation.

Bettio F, Simonazzi A and Villa P (2006) Change in Care Regimes and Female Migration: The 'Care Drain'in the Mediterranean. Journal of European Social Policy, 16(3): 271-285.

Bonazzi G (2002) Come studiare le organizzazioni. Bologna: Il Mulino.

Borghi V and Rizza R (2006) L'organizzazione sociale del lavoro. Lo statuto del lavoro e le sue trasformazioni. Milano: Mondadori.

Borghi V and Van Berkel R (2007) Individualised Service Provision in an Era of Activation and New Governance. International Journal of Sociology and Social Policy, 27(9/10): 413-424.

Brodkin EZ and Marston G (2013) Work and the Welfare State. Street-Level Organisation and Workfare Politics. Washington DC: Georgetown University Press.

Castles S and Miller MJ (1993) The Age of Migration. International Population Movements in the Modem World. New York: Basingstoke.

Caswell D, Larsen F, van Berkel R and Kupka P (2017) Conclusions and Topics for Future Research. In van Berkel R, Caswell D, Kupka P and Larsen F (eds.), Frontline Delivery of Welfare-to-Work Policies in Europe. Activating the Unemployed. London: Routledge.

Catanzaro R and Colombo A (2009) (eds.) Badanti \& Co. Il lavoro domestico straniero in Italia. Bologna: il Mulino.

Cooper H (2001) Homework for All in Moderation. Educational Leadership, 58(7): 34-38.

Davis KC (1969) Discretionary Justice. A Preliminary Inquiry. Louisiana: Louisiana State University Press.

DiMaggio P and Powell W (1983) The Iron Cage Revisited: Institutional Isomorphism and Collective Rationality In Organizational Fields. American Sociological Review, 48: 147-160.

Epp CR (2009) Making Rights Real: Activists, Bureaucrats, and the Creation of the Legalistic State. Chicago: University of Chicago Press.

Epp CR, Maynard-Moody S and Haider-Markel D (2017) Beyond Profiling: The Institutional Sources of Racial Disparities in Policing. Public Administration Review, 77(2): 168-178.

Evans T and Harris J (2004) Street-level Bureaucracy, Social Work and the (Exaggerated) Death of Discretion. British Journal of Social Work, 34(6): 871-895.

Fassin D (2013) La forza dell'ordine. Antropologia della polizia nelle periferie urbane. Bologna: La Linea.

Ferrari S (2002) Event marketing: i grandi eventi e gli eventi speciali come strumenti di marketing. Padova: Cedam.

Fineman S (1998) Street-level Bureaucrats and the Social Construction of Environmental Control. Organization Studies, 19(6): 953-974. 
Flood AB and Fennell ML (1995) Through the Lenses of Organizational Sociology: The Role of Organizational Theory and Research in Conceptualizing and Examining Our Health Care System. Journal of Health and Social Behavior, Extra Issue: 154-169.

FRA (2015) Severe Labour Exploitation: Workers Moving Within or Into the European Union. States' Obligations and Victims' Rights. Vienna: FRA.

Fullin G and Vercelloni V (2009) Dentro la trappola. Percezioni e immagini del lavoro domestico e di cura nei percorsi delle donne immigrate. Polis, 22(3): 427-462.

Garrow EE and Grusky O (2012) Institutional Logic and Street-Level Discretion: The Case of HIV Test Counseling. Journal of Public Administration Research and Theory, 23(1): 103-131.

Geertz C (1982) The Way we Think Now: Toward an Ethnography of Modern Thought. Bulletin of the American Academy of Arts and Sciences, 35: 14-34.

Gilboy JA (1992) Penetrability of Administrative Systems: Political "Casework" and Immigration Inspections. Law \& Society Review, 26(2): 273-314.

Goosensen H and Bueren van E (2011) De professional versus de professionele organisatie: opvattingen over professioneel toezicht, Congres Toezicht en Wetenschap Vide \& TU Delft 21-22 June 2011.

Goosensen HR and Voort van der HG (2009) Risk Based Oversight: the Story of Street-Level Inspectors. In nn (eds.), Proceedings of the Annual Meeting of the Law and Society Association. Denver: Blackwell Publishing.

Ham C and Hill M (1986) Introduzione all'analisi delle politiche pubbliche. il Mulino: Bologna.

Hawkins K (1984) Environment and Enforcement. Regulation and the Social Definition of Pollution. Oxford: Clarendon.

Hupe P (2013) Dimensions of Discretion: Specifying the Object of Street-Level Bureaucracy Research. Der Moderne Staat, 6: 425-440.

Hupe P and Buffat A (2014) A Public Service Gap: Capturing Contexts in a Comparative Approach of Street-Level Bureaucracy. Public Management Review, 16(4): 548-569.

Hupe P and Hill M (2007) Street-level Bureaucracy and Public Accountability. Public Administration, 85(2):279-299.

Hupe P, Hill M and Buffat A (2015) (eds.) Understanding Street-Level Bureaucracy, Bristol: Policy Press.

Kazepov Y and Barberis E (2012) Social assistance governance in Europe. Towards a Multi-level Perspective. In Marx I and Nelson K (eds.), Minimum Income Protection in Flux, Basingstoke: Palgrave Macmillan.

Kelly M (1994) Theories of Justice and Street-Level Discretion Journal of Public Administration Research \& Theory, 4(2): 119-140.

Kluin MAH (2014) Optic Compliance: Enforcement and Compliance in the Dutch Chemical Industry, Delft: Ridderprint.

Lehmann Nielsen V (2006) Are Street-Level Bureaucrats Compelled or Enticed to Cope? Public Administration, 84(4): 861-889.

Lipsky M (1980) Street-Level Bureaucracy. Dilemmas of the Individual in Public Services. New York: Russel Sage Foundation.

Loyens K (2016) Law Enforcement and Policy Alienation - Coping by Labour Inspectors and Federal Police Officers. In Hupe P, Hill M and Buffat A (eds.), Understanding Street Level Bureaucracy. Bristol: Policy Press.

May PJ and Wood RS (2003) At the Regulatory Front Lines: Inspectors' Enforcement Styles and Regulatory Compliance. Journal of Public Administration Research and Theory, 13(2): 117-139.

Maynard-Moody S and Musheno M (2003) Cops, Teachers, Counselors: Stories from the Front Lines of Public Service. Ann Arbor: University of Michigan Press.

Nielsen VL (2007) Differential Treatment and Communicative Interactions: Why the Character of Social Interaction is Important. Law and Policy, 29(2): 257-283.

Piore MJ (2011) Beyond Markets: Sociology, Street Level Bureaucracy and the Management of the Public Sector. Regulation \& Governance, 5: 145-164.

Piore MJ and Schrank A (2006) Trading Up: An Embryonic Model for Easing the Human Costs of Free Markets. Boston Review, 31(5): 11-14.

Piore MJ and Schrank A (2008) Toward Managed Flexibility: The Revival of Labour Inspection in the Latin World. International Labour Review, 147(1): 1-24.

Power M (1997) The Audit Society: Rituals of Verification, Oxford: Oxford University Press. 
Raaphorst N and Loyens K (2018) From Poker Games to Kitchen Tables: How Social Dynamics Affect Frontline Decision Making. Administration \& Society. doi: 0095399718761651.

Rice D (2012) Street-Level Bureaucrats and the Welfare State: Toward a Micro-Institutionalist Theory of Policy Implementation. Administration \& Society, 45(9): 1038-1062.

Riccucci N (2005) Street-Level Bureaucrat and Intrastate Variation in the Implementation of Temporary Assistance for Needy Families Policies. Journal of Public Administration, 15: 89-111.

Sarti R (2010) (eds.), Lavoro domestico e di cura. Quali diritti? Roma: Ediesse.

Saruis T (2015) Gli operatori sociali nel nuovo welfare. Roma: Carocci.

Thornton PH and Ocasio W (2017) Institutional Logics. In Greenwood R, Oliver C, Lawrence TB and Meyer RE (eds.), The Sage Handbook of Organizational Institutionalism, London: Sage.

Wiering M (1999) Contexten van handhaving bij de mestregelgeving in Nederland en Vlaanderen. In Bakker W and van Waarden F (eds.), Ruimte rond regels. Stijlen van regulering en beleidsuitvoering vergeleken. Amsterdam: Boom.

Cite this article: Paraciani R and Rizza R (2019). When the workplace is the home: labour inspectors' discretionary power in the field of domestic work - an institutional analysis. Journal of Public Policy. https://doi.org/10.1017/S0143814X19000254 